\title{
Componential Analysis of Equivalents in Multimodal Translation: A Study of English and Persian Descriptions of Historical Objects in Iranian Museum Captions
}

\author{
Razieh Shivaei \& Hossein Vahid Dastjerdi \\ University of Isfahan
}

\begin{abstract}
Translating the descriptions of museum objects, as a sort of multimodal translation, is now widely used in Iran. English as an international language is the target language of this type of translation which introduces historical and ancient objects to tourists. Although there are many experts of museum affairs in Iran, the significant task of translation in museums lacks language competence on the part of the native translators. In addition, this
\end{abstract}

Razieh Shivaei

English Department, University of Isfahan

Hezar Jarib Ave. Isfahan, Iran.

phone: 00983117932111; Email: rshivaei@ymail.com

Hossein Vahid Dastjerdi

English Department, University of Isfahan

Hezar Jarib Ave. Isfahan, Iran.

phone: 00983117932111; Email: h_vahid@yahoo.com

Received Dec. 2010; Reviewed Dec. 2010; Revised version received Jan. 2011. 
type of translation requires congruity among all museums, for in many cases the names of the same objects are translated differently in different museums. This research was thus aimed at examining the accuracy of English translations of the Persian texts written for historical objects, and suggesting a unified method for this type of translation. The necessary data were initially gathered through photographing 524 historical and ancient objects from 7 main museums in Iran. Then, the information related to the names, raw materials and types of decoration of objects, in both languages (Persian and English), were selected and their meaning components were analysed. The semantic features of both Persian and English terms and their relevant synonyms were then compared and contrasted. Finally, the English terms with the highest degree of correspondence in terms of meaning were specified as the most pertinent equivalents. The findings of the study will be offered to museums as a consistent list of Persian and English equivalents of different names, kinds of materials and types of decoration of objects. This, it is hoped, will remove inconsistency in the translations of museum items at the national level.

Keywords: multimodal translation, componential analysis, semantic feature, museum, accuracy, equivalent

\section{Introduction}

Many of the historical relics of ancient civilization -- now found in museums worldwide -- are the result of archaeological excavations in Iran. Even now, there are a myriad of undiscovered goods and objects under the remains of historical and ancient places waiting to be found, introduced and seen. Since thousands of tourists visit Iran every year and museums are among places most frequently visited by them, the way culture and art are introduced to them is of paramount importance. While objects and goods are the manifestations of a nation's attitude to life, one of the best instances of a nation's culture and art are those of the objects and equipments 
its people made and used every day.

Iran as an ancient country with a long history has always been the habitat of some civilized and creative people. Iranians, since ancient times, have made their required tools by using the best raw materials and manipulating the greatest decorative arts in their time. They have also designed, made, decorated and named their objects according to their own customs and rites and their specific culture. Thus, there are many objects which hardly have an exact correspondence in other languages, especially European languages. English as an international language and a means of introducing the majority of historical and ancient places and museum objects to the world plays the same role as the English translation of Persian texts in Iran. So, the English text of captions of historical places and objects is of paramount importance in forming tourists' conceptions of our culture and art.

When an object is excavated, after the recognition of its antiquity, material, type of decoration and other features, it should be put in a museum and introduced by its features to the public. As the transference of information in museums is done across different semiotic modes and as there is no one source of information in realizing the meaning of a message, museums are considered multimodal areas in which not only the linguistic aspects, but also many other modes such as signs, messages and images transfer and characterize the meaning (Insulander 2007). Since translation is the means of all this activity, the term, 'multimodal translation' is definitely appropriate in this area of investigation.

Although some of English equivalents of the Persian names and descriptions in Iran's museum captions are accurate and to the point, there are a good number of inaccurate ones as well, which necessitate revision. So, the present study aims at finding whether the chosen equivalents are accurate and, if not, what words are the most accurate equivalents and why. The rationale behind the study is to capture the true meaning of the objects and to enable the world 
to truly recognize the implicit value in certain ancient objects and practices.

Since different museums in Iran translate the names and description of their objects on their own (without any general agreement on the English equivalents of common objects in other museums) and sometimes by some inexpert translators, the findings of this study will be put at the disposal of all the museums as an accurate list of English equivalents for different names, kinds of materials and types of decoration of objects.

\section{Background of the Study}

Kress \& van Leeuwen (2001: 20) describe multimodality as 'the use of several semiotic modes in the design of a semiotic product or event, together with the particular way in which these modes are combined'. Multimodal texts are 'texts whose meanings are realized through more than one semiotic code' (Kress \& van Leeuwen 1996: 183). Palumbo (2009: 77) defines multimodality as a term which refers to 'the transmission of meaning through the composite deployment of different semiotic resources, or 'modes'. $\mathrm{He}$ explains that almost no text is absolutely mono-modal, because some extra-linguistic visual elements such as drawings, photographs and graphs are present in most texts. Palumbo notes that meaning in multimodal texts is always the output of the interaction between the verbal and the visual.

Kress and van Leeuwen point out that since multimodality is in relation to the social semiotic theory, the central concepts of this perspective also derive from semiotics. It is worth mentioning that semiotics is based on the assumption that language and the cultural world can be read as signs. In semiotics, sign is defined as 'a unit in which a form has been combined with a meaning or, put differently, a form has been chosen to be the carrier of meaning'. In a social 
semiotic approach, a sign is thus never arbitrary, but motivated by the interest of the sign-maker (Kress \& van Leeuwen 1996/2006: 4-8).

Insulander (2007) in her article explores the museum as a multimodal and social semiotic approach. She mentions that this approach implies a view of communication as a social process of sign-making, where the meaning of a message is realized across several resources or modes of communication (127). She describes that in museums it is not just the linguistic aspects of the exhibition that transfers meaning (128). In a museum, as a multimodal context, many signs, messages, images and other modes characterize an exhibition.

Snell-Hornby (2006: 85) describes four different classes of text that all depend on elements other than the verbal. The first is 'multimedial text' which is conveyed by technical and/or electronic media involving both sight and sound. The second is 'multimodal text' which involves different modes of verbal and nonverbal expressions. The third is 'multisemiotic text' which uses different graphic sign systems, verbal and non verbal. The fourth is 'audiomedial text' which is written to be spoken and received by recipients through human voice.

Remael (2001: 17) states that there is not just one source and one target text in multimodal translation; instead, various source texts impose themselves or are consciously imposed by the sign maker on the translation process. Snell-Hornby (2006: 53) talks about three characteristics of multimodal translation. First, the source text's function typically remains unchanged in the process of translation. Second, the target text is not immediately recognizable as a translation and third, the source text functions as a raw material to serve a particular purpose.

Newmark (1988:114) points out that the basic process of translation is the comparison between a source language (SL) word and a target language (TL) word with similar meanings but with no obvious one-to-one equivalents, by demonstrating their common and 
differing sense components. Besides, in order to choose the most accurate equivalent, a translator needs to think very carefully through the contrastive components in the vocabulary of source and receptor languages (Larson 1984: 86). But, it must be taken into account that a total match between the lexicons of two languages is impossible. Since languages group semantic components together differently, there is no literal and one-to-one equivalent for lexical items. In the systems of two languages, there are some concepts which occur in one language but are unknown in the second language. Even when the same concepts do occur, the way in which they are expressed in the two languages is often very different. So, a translator is to make many adjustments to choose the most accurate equivalent (153-154).

According to Larson (1984: 95), languages decide on their vocabulary depending on the culture, geographical location, and the worldview of their people. There are many words across different languages which share the same central and contrastive components of meaning and yet not be equivalent. Larson (1984: 89) notes that "even though the same THINGS, EVENTS, and ATTRIBUTES may exist in the referential world, the systems of reference do not match one-to-one across languages". Newmark (1988: 115) states that if translation is considered as an ordered rearrangement of sense components that are common to two language communities, then componential analysis is the technique which identifies these components.

As Larson (1984: 96) notes, a translator is not only dealing with concepts in a system of one language, but also concepts in systems of two languages. Since each language describes a particular area of reality or experience differently, a translator wants to be as accurate as possible. So, s/he must examine each word carefully in the systems of two languages to find the word or phrase which most accurately equates with the lexical item used in the source language text. Accuracy in translation is defined as "the extent to which a TT 
reflects the ST in terms of content". Accuracy is actually the correctness of a translation which is achieved by a 'good' or 'right' translation (Palumbo 2009: 6). It is to be noted that according to Newmark (1988) "the only purpose of componential analysis in translation is to achieve the greatest possible accuracy" (17).

Componential analysis is described as the analysis of the basic components of meaning of a given word. It is a kind of analysis that deals with the lexical meaning which is based on sense and sense components (Palumbo 2009: 22). In componential analysis, CA for short (Saeed 2003: 260), the meaning of each word is dependent upon the components it possesses and the way they are organized. The essential assumption of CA is the fact that the meaning of a word is a combination of its elements of meaning which are binary and marked as present or absent (+ or -) (Bell 1991: 87-88). James (1980: 93-94) points out that + is to mark the lexeme by having the relevant component and - is to mark the lack of the relevant component. Besides, 0 is used to signify that the lexeme does not apply distinctively one way or other.

In componential analysis, it is essential to have words in sets which share and differ in some features of meaning (Larson 1984: 80). The shared features are called central or generic components that unite any semantic set and are shared by all words. The nuanced features are called contrastive components which distinguish a word from all other words of the set (84). The relationship between the central component and the contrastive component is always one of delimitation; the contrastive components narrow down the meaning of the central component (87).

As the purpose of the present study is to find the most accurate English equivalents of the Persian words and phrases of the descriptions of historical objects in museums, it is done within the framework of componential analysis. Thus, the most accurate English equivalents are those with the highest correspondence in central and the lowest correspondence in contrastive components as 
204 Componential Analysis of Equivalents

compared with their counterpart Persian texts.

\section{Method}

This study aimed to analyse the English equivalents of Persian names, materials and decorations of historical objects used in captions in Iranian museums. The method of data analysis was componential analysis (CA) in which the meaning of a word is separated into smaller units called semantic features. In the application of CA in translation, semantic features of SL words were compared and contrasted with their TL equivalents. As a consequence, the most accurate and correct equivalents, in which the highest correspondence between semantic features of SL and TL words exist, were determined. The results of the matches and mismatches between semantic features of SL and TL words were then illustrated by + , - and 0 signs in a set of tables. Then, the number of signs for each word was indicated in another set of tables. At last, based on all the findings, the most accurate equivalents were identified and suggested.

The analysis of the data in this study started from the cross checking of all Persian and English words (used in captions, related to the names, materials and decorations of historical objects) in monolingual (Persian to Persian or English to English) dictionaries and encyclopaedias. According to Newmark (1988: 115-117), as monolingual dictionaries are trustworthy evidences of any language, CA attempts to go far beyond bilingual dictionaries and put its basis on monolingual dictionaries. The employed monolingual Persian dictionaries were 'Loghatnameh Dehkhoda' (2010), 'Moin Dictionary' (2009), and 'Amid Dictionary' (1981). The monolingual English dictionaries were 'Oxford Talking Dictionary' (1998), 'Encarta Dictionary' (2006), 'Merriam-Webster Online Dictionary' (2010), 'Cambridge Advanced Learner's Dictionary- $2^{\text {nd }}$ edition' (2010) and 


\section{'Longman Dictionary of Contemporary English' (2000).}

Finally, the acquired meanings of each word (Persian and English) were unified and then separated into smaller components called 'semantic features'. Semantic features of the Persian words and their suggested English equivalents were then compared and contrasted with each other. The results of the matches and mismatches between semantic features of Persian and English words were illustrated by,+- and 0 signs in a set of tables. It is to be noted that the researchers considered some conditions for each semantic feature to be marked,+- or 0 . The conditions are elaborated below:

Conditions for taking the sign + are twofold. First, it is clearly stated in the definitions of a lexeme, in different dictionaries, that it has a specific feature. And second, it is logically comprehensible from the definitions of a lexeme, in different dictionaries, that it has a specific feature. For instance, in the definitions of the word 'pitcher', it is mentioned that it has a spout or lip. So, it can be deduced that 'pitcher' is used for pouring liquids.

Conditions for taking the sign - are also twofold. First, it is clearly stated in the definitions of a lexeme, in different dictionaries, that it has not a specific feature. And second, it is logically comprehensible from the definitions of a lexeme, in different dictionaries, that it has not a specific feature. For instance, in the analysis of the word 'شيشه' (/shisheh/) in Persian and its suggested English equivalents in museums, the ingredients of 'شيشّ' (/shisheh/), in its definitions, are introduced as 'a combination of sand with other oxides such as lime or soda'. While, the ingredients of 'ceramic', one of the suggested equivalents, are explained as 'a mixture of clay and chemicals'. So, it is logically comprehensible that 'ceramic' lacks the specific raw materials of 'شيشّه' (/shisheh/) in Persian.

Conditions for taking the sign 0 are threefold. First, it is clearly stated in the definitions of a lexeme, in different dictionaries, that it may or may not have a specific feature. For instance, in the definitions of 'bottle', it is clearly mentioned that it can be with or 
without handle. This kind of 0 sign is shown as $0(\mathrm{~A})$ in the tables. Second, there is a feature which is not mentioned in the definitions of a lexeme but, it does not necessarily mean that the lexeme lacks it. For instance, the word 'تتخ' (/tong/) in Persian is defined as a 'cylindrical vessel'. However, this feature is not mentioned in the definitions of bottle, one of the suggested English equivalents of 'تنـ' (/tong/). Therefore, it cannot be deduced that 'bottle' lacks the 'cylindrical' feature of 'تיָ' (/tong/) in Persian. This kind of 0 sign is shown as 0 (B) in the tables. And third, there is a semantic feature of a Persian lexeme which is partially carried on to its suggested English equivalent. In other words, when a specific feature of an English lexeme is not completely the same as that feature in its Persian equivalent lexeme, it is marked by 0 (C) in the table. For instance, the materials from which bottle is usually made are introduced as 'leather, plastic and glass' but, 'تتگ' (/tong/) in Persian is usually made of earthenware or glass. So, 'glass' is common in the definitions of 'تنگ' (/tong/) in Persian and bottle in English but, materials such as leather and plastic for 'تنگ' (/tong/) in Persian and earthenware for bottle in English are not mentioned in their definitions. Therefore, the feature of material for bottle in English is considered incomplete and marked by 0 (C) sign.

\section{Data Analysis, Results and Discussion}

In the present section, a number of equivalents for the name of objects, materials and decorations are selected and analysed through componential analysis method, and the results are shown in a set of tables. In this section, any description presented for Persian or English words is the result of the unification of different definitions of the word gained from different dictionaries. So, the references of the descriptions of words (Persian or English) are not stated. Nevertheless, all of the words (Persian and English) and their 
definitions, suggested by the examined dictionaries, are listed at the end of the paper, in the appendix section.

\section{1. 'تنگ' (/tong/)}

The componential analysis of the Persian word 'تنگ' (/tong/) and its suggested English equivalents is illustrated in Table 1. below:

Table 1. Componential Analysis of 'تنگ' (/tong/)

\begin{tabular}{|c|c|c|c|c|c|c|c|c|}
\hline 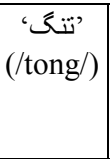 & $\begin{array}{l}\text { Vase } \\
\text { Shaped }\end{array}$ & Cylindrical & Handled & $\begin{array}{c}\text { With } \\
\text { a } \\
\text { Wide } \\
\text { Base }\end{array}$ & $\begin{array}{c}\text { With a } \\
\text { Narrow } \\
\text { Neck }\end{array}$ & $\begin{array}{c}\text { Short } \\
\text { Necked }\end{array}$ & $\begin{array}{c}\text { Earthenware } \\
\text { or Glass }\end{array}$ & $\begin{array}{l}\text { With } \\
\quad \text { a } \\
\text { Spout } \\
\text { or Lip }\end{array}$ \\
\hline Carafe & $0(\mathrm{~B})$ & + & + & + & + & 0 (B) & $0(\mathrm{C})$ & 0 (B) \\
\hline Pitcher & + & + & + & + & + & $0(\mathrm{~B})$ & $0(\mathrm{C})$ & + \\
\hline Ewer & + & + & 0 (B) & + & + & 0 (B) & $0(\mathrm{~B})$ & + \\
\hline Jug & + & + & + & + & + & $0(\mathrm{~B})$ & + & + \\
\hline Bottle & $0(\mathrm{~B})$ & $0(\mathrm{~B})$ & $0(\mathrm{~A})$ & 0 (B) & + & $0(\mathrm{~B})$ & $0(\mathrm{C})$ & $0(\mathrm{~B})$ \\
\hline
\end{tabular}

The features of 'vase shaped', 'short necked' and 'with a spout or lip' are not mentioned in the definitions of the word 'carafe'. But, it does not mean that 'carafe' lacks these features. So, all are marked by 0 (B) in Table 1 . Besides, in the definitions of the word 'carafe' in different dictionaries, the material from which 'carafe' is usually made is introduced as 'glass'. As 'تنگ' (/tong/) is made of 'earthenware or 'glass", 'carafe' has an incomplete feature, in comparison to that of 'تنگ' (/tong/) in Persian, in the case of material. Therefore, it is marked by 0 (C) in Table 1 . The other features of 'cylindrical', 'handled', 'with a wide base' and 'with a narrow neck' are present in the definitions of the word 'carafe' and so marked by + in Table 1 .

In the definitions of the word 'pitcher', the feature 'short necked' is not mentioned. But, it does not mean that 'pitcher' lacks this 
feature. So, it is marked by 0 (B) in Table 1 . In the case of material, as the word 'pitcher' is introduced, in dictionaries, to be made of earthenware and 'تنگ' (/tong/) as made of 'earthenware or glass', 'pitcher' has also an incomplete feature, in comparison to that of 'تنگ' (/tong/) in Persian. Therefore, it is marked by 0 (C) in Table 1. The other features of 'vase shaped', 'cylindrical', 'handled', 'with a wide base', 'with a narrow neck' and 'with a spout or lip' are present in the definitions of the word 'pitcher' and so marked by + in Table 1.

In the case of the word 'ewer', the features of 'handled', 'short necked' and 'earthenware or glass' are not mentioned in its definitions in different dictionaries. But, it does not mean that 'ewer' lacks these features. So, all are marked by 0 (B) in Table 1 . As the other features of 'vase shaped', 'cylindrical', 'with a wide base', 'with a narrow neck' and 'with a spout or lip' are present in the definitions of the word 'ewer', they are all marked by + in Table 1. For the word 'jug', the feature of 'short necked' is not mentioned in the definitions of this object in different dictionaries. So, it is marked by 0 (B) in Table 1. Since all other features of 'تنت (/tong/) in Persian are distinct features of 'jug' as well, they are all marked by + in Table 1 .

In the definitions of the word 'bottle' in different dictionaries, there is no indication of 'vase shaped', 'cylindrical', 'with a wide base', 'short necked' and 'with a spout or lip' features. Since it does not mean that 'bottle' lacks any of them, they are all marked by 0 (B) in Table 1. In some dictionaries the word 'bottle' is introduced as 'with or without handle'. So, the feature of 'handled' for 'bottle' is marked by 0 (A) in Table 1 . In addition, the materials from which 'bottle' is usually made are pointed out as 'leather, glass or plastic'. Therefore, as 'تتخ' (/tong/) is made of 'earthenware or glass', the material feature of 'bottle' is considered incomplete and marked by $0(\mathrm{C})$. 


\section{2. 'شيشه' (/shisheh/)}

The componential analysis of the Persian word 'شيشا' (/shisheh/) and its suggested English equivalents is illustrated in Table 2 below:

Table 2. Componential Analysis of 'شيشّ' (/shisheh/)

\begin{tabular}{|c|c|c|c|c|}
\hline $\begin{array}{c}\text { 'شيشّ' } \\
\text { (/shisheh/) }\end{array}$ & $\begin{array}{c}\text { Made by } \\
\text { Melting Sand in } \\
\text { Combination } \\
\text { with Other } \\
\text { Oxides Such as } \\
\text { Lime or Soda }\end{array}$ & Transparent & Lustrous & $\begin{array}{c}\text { Hard and } \\
\text { Brittle }\end{array}$ \\
\hline \hline Frit & - & $0(\mathrm{~B})$ & $0(\mathrm{~B})$ & - \\
\hline Glass & + & + & + & + \\
\hline Ceramic & - & - & - & + \\
\hline
\end{tabular}

The word 'frit' is defined in different dictionaries as 'the basic melted materials from which glass, pottery glazes or enamels are made at the beginning of the manufacturing process'. It is also described as 'a calcined mixture of silica and fluxes'. So, its ingredients are completely different from those of 'شيشه' (/shisheh/) in Persian. Therefore, the first feature is marked by - for 'frit'. As 'frit' is a melted liquid, it is obviously not 'hard and brittle'. So, this feature is marked by - in Table 2. The other two features of 'transparent' and 'lustrous' are not mentioned in the definitions of the word 'frit' and they are marked by 0 (B) in Table 2 .

The word 'glass' has all of the semantic features of 'شيشَ' (/shisheh/) in Persian. So, all of the features are marked by + for the word 'glass' in Table 2. The ingredients of 'ceramic' are defined as 'a mixture of clay and chemicals' which are different from those of 'شيشه' (/shisheh/). So, the first feature is marked by - for the word 'ceramic'. As 'ceramic' is made of clay, as the basic material, it is 
obviously not transparent or lustrous. Therefore, the other two features are also marked by - in Table 2 . But, it is clearly stated in the definitions of 'ceramic' that it is 'hard and brittle'. So, the last feature is marked by + in Table 2 .

\section{3. 'كاسهة' (/kaaseh/)}

The componential analysis of the Persian word 'كاسـ' (/kaaseh/) and its suggested English equivalents is illustrated in Table 3 below:

Table 3. Componential Analysis of 'كاسا،' (/kaaseh/)

\begin{tabular}{|c|c|c|c|c|}
\hline $\begin{array}{c}\text { ('/kaaseh/) } \\
\text { (Shape } \\
\text { and Round in } \\
\text { Shape }\end{array}$ & $\begin{array}{c}\text { To } \\
\text { Hold/Carry } \\
\text { Liquids or } \\
\text { Food }\end{array}$ & $\begin{array}{c}\text { To Eat } \\
\text { Liquids or } \\
\text { Food from }\end{array}$ & $\begin{array}{c}\text { Made of } \\
\text { Metal, } \\
\text { Wood, } \\
\text { Ceramic or } \\
\text { China }\end{array}$ \\
\hline \hline Bowl & + & + & $0(\mathrm{~B})$ & $0(\mathrm{~B})$ \\
\hline Vessel & $0(\mathrm{~B})$ & $0(\mathrm{C})$ & $0(\mathrm{C})$ & $0(\mathrm{C})$ \\
\hline Jar & $0(\mathrm{C})$ & $0(\mathrm{C})$ & $0(\mathrm{~B})$ & $0(\mathrm{C})$ \\
\hline
\end{tabular}

A 'bowl' is an object 'hemispherical and round in shape' which is used 'to carry or hold liquids or food', the same as 'كاسه' (/kaaseh/) in Persian. So, the first two features are marked by + in Table 3. But, as 'كاسس،' (/kaaseh/) in Persian is 'made of wood, ceramic or china' and it is used 'to eat liquids or food from', and these two feature are not mentioned in the definitions of the word 'bowl' in different dictionaries, they are marked by 0 (B) in Table 3. In different dictionaries, the word 'vessel' is defined as 'a hollow container' and there is no indication of rather it is round or hemispherical. In addition, being hollow does not necessarily mean being hemispherical. So, the first feature is marked by 0 (B) in Table 3. Besides, the word 'vessel' is defined as 'a container for liquids' and there is no point to 'food' in its definitions. Therefore, 
the second and third features are not completely carried on in semantic features of the word 'vessel' and are marked by 0 (C) in Table 3. In the case of the material, as 'vessel' is defined to be made of gold or silver, it is also incomplete in this feature and marked by 0 (C) in Table 3.

As the word 'jar' is defined as a cylindrical vessel it is not hemispherical but it is round in shape. So, the first feature is not completely carried on in the semantic features of the word 'jar' and is marked by $0(\mathrm{C})$ in Table 3. The word 'jar' is described as 'a container for holding water, oil, wine, etc.' and there is no indication of food in its definitions. Therefore, the second feature is incomplete in 'jar' and marked by 0 (C) in Table 3. In addition, it is not introduced as a vessel from which something is eaten. So, the third feature is marked by 0 (B) in Table 3. The materials from which ' $\mathrm{jar}$ ' is usually made is described as 'glass, earthenware and stoneware' which is not exactly the same as those of 'كاسه' (/kaaseh/) in Persian. So, it is also marked by 0 (C) in Table 3.

\section{4. 'قلمدان' (/ghalamdaan/)}

The componential analysis of the Persian word 'قلمدان' (/ghalamdaan/) and its suggested English equivalents is illustrated in the Table 4 below:

Table 4. The Componential Analysis of 'قلمدان' (/ghalamdaan/)

\begin{tabular}{|c|c|c|c|}
\hline $\begin{array}{c}\text { 'قلمدان' } \\
\text { (/ghalamdaan/) }\end{array}$ & $\begin{array}{c}\text { A Small and } \\
\text { Long Box }\end{array}$ & $\begin{array}{c}\text { Of Wood or } \\
\text { Paper }\end{array}$ & $\begin{array}{c}\text { Used for Holding } \\
\text { Writing Equipment }\end{array}$ \\
\hline \hline Pen box & + & + & + \\
\hline Pen case & - & - & - \\
\hline
\end{tabular}

The phrase 'pen box' which is suggested by a museum is not a normal collocation in English, but it is used by Fehervari (1976, p. 
plate 25) in 'Islamic metalwork of the English to the fifteenth century in the Keir collection' in the introduction of an object exactly the same as what is called 'قلمدان' (/ghalamdaan/) in Persian. So, all of the features of 'قلمدان' (/ghalamdaan/) are marked by + in Table 4. The phrase 'pen case' is not found anywhere in dictionaries or museum encyclopedias as an accepted combination in English or something referring to what is called 'قلمدان' (/ghalamdaan/) in Persian. So, all of the features of 'قلمدان' (/ghalamdaan/) are marked by - in Table 4.

\section{5. 'لعاب (/laab/)}

The componential analysis of the Persian word 'لعاب' (/laab/) and its suggested English equivalents is illustrated in Table 5 below:

Table 5. Componential Analysis of 'لعاب' (/laab/)

\begin{tabular}{|c|c|c|c|c|}
\hline 'لعاب، (/laab/) & $\begin{array}{l}\text { A Mixture of } \\
\text { Oxides Such } \\
\text { as Silica and } \\
\text { Alumina }\end{array}$ & $\begin{array}{l}\text { Applied to the } \\
\text { Surface of } \\
\text { Ceramic } \\
\text { Wares, Tiles, } \\
\text { etc. }\end{array}$ & $\begin{array}{l}\text { To Form a } \\
\text { Lustrous and } \\
\text { Ornamental } \\
\text { Coating }\end{array}$ & $\begin{array}{c}\text { Fired in a Kiln } \\
\text { to Fix the } \\
\text { Coloration }\end{array}$ \\
\hline Glaze & + & + & + & + \\
\hline Luster & 0 (B) & + & $0(\mathrm{C})$ & $0(\mathrm{C})$ \\
\hline
\end{tabular}

The word 'glaze' has all of the semantic features of 'لعاب' (/laab/) in Persian. In addition, Mirhadi (2006: 330) and Masood (1997: 216) introduce the word 'glaze' as 'لعاب' (/laab/) in Persian. So, it is marked by + in all cases. 'Luster' is actually a special kind of glaze which is an iridescent metallic decorative surface applied to an already-fired glaze. It is said that the precious metals such as gold, silver and platinum are used in 'luster'. It is worth mentioning that Mirhadi (2006: 441) suggests the word 'جلا' (/jala/) as the Persian translation of the word 'luster' in English. As there is no mentioning 
of 'mixture of oxides such as silica and alumina' in definitions of the word 'luster', the first feature is marked by 0 (B) in Table 5. The word 'luster' shares the second feature and gets a + sign in this case. As the third feature of the word 'glaze' lacks the 'metallic appearance' of 'luster', this feature is incomplete for 'luster' and so marked by $0(\mathrm{C})$ in Table 5. As mentioned before, 'luster' is applied to an already fired glaze and since this is not mentioned in the forth semantic feature, it is marked by $0(\mathrm{C})$ in Table 5 .

\section{6. 'طلاكوب' (/talakub/)}

The componential analysis of the Persian word 'طلاكوب' (/talaakoob/) and its suggested English equivalents is illustrated in Table 6 below:

Table 6. Componential Analysis of 'طلاكوب' (/talaakoob/)

\begin{tabular}{|c|c|c|}
\hline 'طلاكوب' (/talaakoob/) & $\begin{array}{c}\text { A Thing that is } \\
\text { Decorated by Gold }\end{array}$ & $\begin{array}{c}\text { The Gold is Filled into } \\
\text { Some Cavities on the } \\
\text { Surface }\end{array}$ \\
\hline \hline Gilded & + & - \\
\hline inlaid in gold & + & + \\
\hline
\end{tabular}

The word 'gilded' and the phrase 'inlaid in silver' are suggested as English equivalents respectively for 'طلاكوب' (/talaakoob/) and 'نقره كوبى' (نقره كوب' (/noghrekoob/) in Persian. As the processes of (طلاكوبى' (/noghrekoobi/) and (talakoobi/) are the same, the English equivalents of these two Persian words should be the same with a nuance in gold or silver. Gilding refers to the process of applying a thin layer of gold leaf wholly or partially to the surface of something. Moreover, in the book British Museum Guide (1976: 117-118), the vessels on which some designs are colored by gold are called 'gilt'. Mirhadi (2006: 326) and Masood (1997: 214) define the process of 'gilding' as applying a thin layer of gold leaf wholly 
or partially to the surface of something. Nevertheless, 'طلاكوبى' (/talaakoobi/) in Persian is filling of some spaces on the surface of an object by small pieces of gold. So, the first feature of 'طلاكوب' (/talaakoob/) is carried on in gild's semantic features and it is marked by + in Table 6 . But, as the second feature is not applied in gilding in English, it is marked by - in the same Table.

Inlaying in English refers to the process of decorating something with a substance of a different kind by inserting it into some cavities on the surface of the object in a decorative design. The point is that the substance of decoration is different from the material of the main object. So, inlaying is congruent with the process of 'طلاكوبى' (/talaakoobi/) and 'نقره كوبى' (/noghrekoobi/) in Persian in the case of the both features. Therefore, they are marked by + in Table 6 . It is worth mentioning that 'inlaid in gold', which is suggested by a museum, refers to an inlaying process which is done on a golden object, while 'طلاكوبى' (/talaakoobi/) is the decoration of an object of a different substance- by small pieces of gold. In some books such as British Museum Guide (1976: 133), Islamic Metalwork of the English to the Fifteenth Century in the Keir Collection (1976: 57) and Islamic Art (1972: 214), the phrase 'inlaid with gold' is used for describing objects with such a decoration we call 'طلاكوب' (/talaakoob/) in Persian. The phrase 'inlaid with gold' refers to the decoration of an object, made of a material other than gold, by pieces of gold. So, the phrase 'inlaid with gold' is preferred to the 'inlaid in gold'.

\section{7. كوزه' (/koozeh/)}

The componential analysis of the Persian word 'كوزه' (/koozeh/) and its suggested English equivalents is illustrated in Table 7 below: 
Table 7. Componential Analysis of 'كوزه' (/koozeh/)

\begin{tabular}{|c|c|c|c|c|}
\hline $\begin{array}{c}\text { 's } 0 \text { ' } \\
(/ \text { koozeh/) }\end{array}$ & $\begin{array}{c}\text { A Vessel } \\
\text { with a } \\
\text { Narrow and } \\
\text { Long Neck }\end{array}$ & $\begin{array}{c}\text { To Hold } \\
\text { Liquids }\end{array}$ & $\begin{array}{c}\text { With or } \\
\text { without } \\
\text { Handle }\end{array}$ & Earthenware \\
\hline \hline Jug & $0(\mathrm{~B})$ & + & + & $0(\mathrm{C})$ \\
\hline Bottle & + & + & + & $0(\mathrm{C})$ \\
\hline Jar & $0(\mathrm{~B})$ & + & + & $0(\mathrm{C})$ \\
\hline Pot & - & $0(\mathrm{C})$ & $0(\mathrm{~B})$ & $0(\mathrm{C})$ \\
\hline
\end{tabular}

In the definitions of the word 'jug', there is no indication of the 'neck' of the vessel. So, the first feature is marked by 0 (B) in Table 7. But, as it is clearly stated that 'jug' is to hold liquids, the second feature is marked by + in Table 7. Since the word 'jug' is defined as a handled vessel, the third feature is carried on it and so marked by + in Table 7. In the definitions of the word 'jug', the materials from which 'jug' is made are introduced as 'earthenware or glass'. Since 'كوزه' (/koozeh/) in Persian is defined as being made of earthenware, the last feature is marked by 0 (C) in Table 7 . In the case of the word 'bottle', it is exactly the same as 'كوزه' (/koozeh/) in Persian in the case of the first three features. So, they are all marked by + in Table 7. In different dictionaries, the materials from which 'bottle' is usually made are introduced as leather, glass or plastic. However, since Fournier (2000) introduces an object made of earthenware as 'bottle', the last feature is a part of bottle's materials and marked by 0 (C) in Table 7. In addition, some books such as Ancient Glass in the Freer Gallery of Arts (1962: 13-24) and Islamic Pottery: a comprehensive study based on the Barlow Collection (1973: 168) introduce a vessel (a bottle) of the same shape as 'كوزه' (/koozeh/) in Persian.

In the definitions of the word 'jar', there is no indication of the 'neck' of the vessel. So, the first feature is marked by 0 (B) in Table 7. But, as it is clearly stated that 'jar' is to hold liquids, the second 
feature is marked by + in Table 7. Since the word 'jar' is defined as a vessel with no handle or with two handles, the third feature is completely carried on it and so marked by + in Table 7 . In the definitions of 'jar', the materials from which 'jar' is made are introduced as earthenware, stoneware or glass. Since 'كوزه' (/koozeh/) in Persian is defined as being made from earthenware, the last feature is marked by $0(\mathrm{C})$ in Table 7. As 'pot' is a vessel with an open top, it has no neck. So, the first feature is marked by - in Table 7. In addition, the word 'pot' is defined as a container for both liquid and solid substances. Therefore, the second feature is marked by 0 (C) in Table 7 . Since there is no indication of handle in the definitions of 'pot', the third feature is marked by 0 (B) in Table 7. In the definitions of 'pot', the materials from which 'pot' is made are introduced as earthenware, metal or glass. So, the last feature is marked by 0 (C) in Table 7 .

\section{8. 'خاتم كارى' (/khaatamkaari/)}

The componential analysis of the Persian phrase 'خاتم كارى' (/khaatamkaari/) and its suggested English equivalents is illustrated in Table 8 below:

Table 8. Componential Analysis of 'خاتم كارى' (/khaatamkaari/)

\begin{tabular}{|c|c|c|c|c|}
\hline $\begin{array}{c}\text { (/khaatamkaari/) } \\
\text { (اتارى }\end{array}$ & $\begin{array}{c}\text { An } \\
\text { Ornamentation } \\
\text { Process }\end{array}$ & $\begin{array}{c}\text { Decorating } \\
\text { Objects by } \\
\text { Small Pieces } \\
\text { of Wood, } \\
\text { Metal, Ivory } \\
\text { or Bone }\end{array}$ & $\begin{array}{c}\text { In a Design of } \\
\text { Geometrical } \\
\text { Patterns }\end{array}$ & $\begin{array}{c}\text { The Small } \\
\text { Pieces with } \\
\text { Geometrical } \\
\text { Patterns are } \\
\text { First Matched } \\
\text { Together and } \\
\text { then to the } \\
\text { Surface of an } \\
\text { Object }\end{array}$ \\
\hline \hline Cachet & + & - & - & - \\
\hline Inlaying & + & + & $0(\mathrm{~B})$ & + \\
\hline
\end{tabular}


The word 'cachet' in English refers to a design or inscription on an envelope to commemorate a postal or philatelic event. As there is no relation between 'خاتم كارى' (khaatamkaari/) in Persian and 'cachet' in English, all of the semantic features, except the first one, are marked by - in Table 8. The word 'inlaying' in English refers to 'خانت كارى" (/khaatamkaari/) in Persian. As there is no indication of 'geometrical patterns' in the definitions of 'inlaying' in English, the third feature is marked by 0 (B) in Table 8 . Since the all other semantic features of 'خاتم كارى' (khaatamkaari/) in Persian are in correspondence with those of 'inlaying' in English, they are all marked by + in Table 8. In addition, Ettinghausen (1972: 305) in Islamic Art uses the phrase 'inlaid chair' for a chair which is called 'خاتم كارى شده' (/khaatamkaari shode/) in Persian.

\section{9. 'بياه سوز (/pihsooz/)}

The componential analysis of the Persian word ' بوز سوز" (/pihsooz/) and its suggested English equivalents is illustrated in Table 9 below:

Table 9. Componential Analysis of ' بويه سوز' (/pihsooz/)

\begin{tabular}{|c|c|c|c|c|c|}
\hline $\begin{array}{c}\text { '/pihsooz/) } \\
\text { (/pist }\end{array}$ & A Lamp & $\begin{array}{c}\text { Of Metal or } \\
\text { Earthenware }\end{array}$ & $\begin{array}{c}\text { In which } \\
\text { Oil is } \\
\text { Burnt }\end{array}$ & $\begin{array}{c}\text { The Oil is } \\
\text { Got from } \\
\text { Animals or } \\
\text { Plants }\end{array}$ & $\begin{array}{c}\text { Usually with } \\
\text { a Wick to } \\
\text { Provide } \\
\text { Illumination }\end{array}$ \\
\hline \hline Lamp & + & $0(\mathrm{~B})$ & $0(\mathrm{C})$ & $0(\mathrm{~B})$ & + \\
\hline Oil lamp & + & 0 (B) & + & + & + \\
\hline Tallow lamp & + & 0 (B) & + & $0(\mathrm{C})$ & + \\
\hline $\begin{array}{c}\text { Tallow } \\
\text { burner }\end{array}$ & $0(\mathrm{~B})$ & 0 (B) & + & $0(\mathrm{C})$ & $0(\mathrm{~B})$ \\
\hline
\end{tabular}


The word 'lamp' which is suggested by a museum as an equivalent for 'بِيه سوز' (/pihsooz/) in Persian is congruent in the first and last features with those of the word 'بيه سوز' (/pihsooz/) in Persian. So, these features are marked by + in Table 9. As there is no indication of the material from which 'lamp' is made, in the definitions of 'lamp', the second feature is marked by 0 (B) in Table 9. As the word 'lamp' is defined as a vessel in which oil, gas or wax is burnt and in the definitions of the word 'بِيه سوز' (/pihsooz/) in Persian there is no indication of gas being burnt in it, the third feature is considered in complete and so marked by 0 (C) in Table 9. Since the source of the fuel which is burnt in 'lamp' is not mentioned in the definitions of it, the forth feature is marked by 0 (B) in the table.

As 'oil lamp' is obviously a kind of lamp, the first feature is marked by + for it in Table 9. As there is no indication of the material from which 'lamp' and consequently 'oil lamp' are made, the second feature is marked by 0 (B) in Table 9. Since a kind of oil is, obviously, used in 'oil lamp', the third feature is marked by + in Table 9. As the word 'oil' in different dictionaries is defined as a combustible substance obtained from plant seeds or animal fats, the forth feature is marked by + in Table 9. In addition, a lamp has a wick to provide illumination. So, the last feature is marked by + in Table 9. It is worth mentioning that in the book Islamic Metalwork of the English to the Fifteenth Century in the Keir Collection (Fehervari: 1976, plate 36), the phrase 'oil lamp' is used for an object in the same shape and function of 'بيه سوز' (/pihsooz/) in Persian.

As 'tallow lamp' is a kind of lamp, the first feature is marked by + for it in Table 9. Since there is no indication of the material from which 'lamp' and consequently 'tallow lamp' is made, the second feature is marked by 0 (B) in Table 9. As 'tallow' is a kind of 'oil' the third feature is marked by + in Table 9 , but as it is just taken from animal fat, the forth feature is considered incomplete and 
marked by 0 (C) in Table 9. Moreover, since a lamp hast a wick to provide illumination, the last feature is marked by + in Table 9.

In the case of 'tallow burner', as the word 'burner' is not described as a 'lamp' but 'a part of a fuel-burning and heating device' and there is no indication of the material from which it is made, the first two features are marked by 0 (B) in Table 9. As 'tallow' is a kind of 'oil' the third feature is marked by + in Table 9., but as it is just taken from animal fat, the forth feature is considered incomplete and marked by 0 (C) in Table 9 . In definitions of the word 'burner' there is no indication of 'wick'. So, the last feature is marked by 0 (B) in Table 9 .

\subsection{0. 'قنديل' (/ghandil/)}

The componential analysis of the Persian word 'قنديل' (/ghandil/) and its suggested English equivalents is illustrated in the Table 10 below:

Table 10. Componential Analysis of 'قنديل' (/ghandil/)

\begin{tabular}{|c|c|c|c|}
\hline $\begin{array}{c}\text { 'قنديل' } \\
\text { (/ghandil/) }\end{array}$ & A Container & $\begin{array}{c}\text { In which There } \\
\text { is a Lamp }\end{array}$ & $\begin{array}{c}\text { Usually Hung } \\
\text { from the Roof }\end{array}$ \\
\hline \hline Lantern & + & + & 0 (B) \\
\hline Mosque Lamp & - & - & - \\
\hline
\end{tabular}

The word 'lantern' is the same as 'قنديل' (/ghandil/) in Persian in the first two semantic features. So, the first semantic features are marked by + in the table. In the definitions of the word 'lantern' in different dictionaries, there is no indication of 'hanging from the roof' as a main feature, but it is mentioned that lantern is portable. So, the last feature is marked by 0 (B) in Table 10. Moreover, Fehervari (1976: plate 33) introduces a picture of what is called 'قنديل' (/ghandil/) in Persian as a 'lantern' in English. The phrase 
'mosque lamp' is not a normal and accepted collocation in English and not found in any dictionary. So, all of the semantic features are marked by - for it in Table 10.

\section{Conclusion}

Below are a set of tables that show the extent of correspondence and disparity between semantic features of Persian words and those of their suggested English equivalents. In addition, each table contains the names of the museums in which the object and English translation of its caption are shown. Following each table, the most accurate equivalent, i.e. the one with the highest number of the matching sign $(+)$, is presented. Also, based on the obtained results, the calculated percentage of the accurate English equivalents of each case is presented at the end of each section. In order to arrive at a general conclusion of the present study, the average percentages of the accurate translations in museums, i.e. the extent of translation accuracy of museum objects, are provided in this section, and the museums with the highest number of accurate English equivalents are introduced.

\section{1. 'تنع' (/tong/)}

Table 11 below illustrates the number of matches $(+)$, mismatches (-) and partial matches (0) for the Persian word 'تتح' (/tong/) and its suggested English equivalents. 
Table 11. The Scores of Each Sign for the English Equivalents of the Persian Word 'تنگ' (/tong/)

\begin{tabular}{|c|c|c|c|c|}
\hline $\begin{array}{l}\text { Museum } \\
\text { Names }\end{array}$ & Words & + & - & 0 \\
\hline آرامحاه فردوسى & Carafe & 4 & 0 & 4 \\
\hline باستان و آستان قدس آبران & Pitcher & 6 & 0 & 2 \\
\hline آبخينه & Ewer & 5 & 0 & 3 \\
\hline آبكينه & Jug & 7 & 0 & 1 \\
\hline آبكينه & Bottle & 1 & 0 & 7 \\
\hline
\end{tabular}

According to Table 11, and based on the highest score of the word 'jug', 'jug' has the most in common with semantic features of 'יتگ (/tong/) in Persian and can be the most accurate English equivalent of it. After 'jug', 'pitcher' has the most common with 'تنگ' (/tong/) in Persian. According to Fournier (2000), the word 'jug' in British English and the word 'pitcher' in American English refers to the same object, called 'تتخ' (/tong/) in Persian. Among the 7 cases of occurrence of the word 'تنّ' (/tong/) in museum captions, 3 cases included the accurate English translation. This means that $42.8 \%$ of the translations were accurate.

\section{2. 'شيشه' (/shisheh/)}

Table 12 below illustrates the number of matches $(+)$, mismatches (-) and partial matches (0) for the Persian word 'شيشه' (/shisheh/) and its suggested English equivalents. 
222 Componential Analysis of Equivalents

Table 12. The Scores of Each Sign for the English Equivalents of the Persian Word 'شيشّ' (/shisheh/)

\begin{tabular}{|c|c|c|c|c|}
\hline $\begin{array}{l}\text { Museum } \\
\text { Names }\end{array}$ & Words & + & - & 0 \\
\hline آر امشاه فردوسى & Frit & 0 & 2 & 2 \\
\hline اير ان باستان & Glass & 4 & 0 & 0 \\
\hline اير ان باستان & Ceramic & 1 & 3 & 0 \\
\hline
\end{tabular}

According to Table12, and based on the highest score of the word 'glass', the word 'glass' is the most accurate equivalent for the 'شيشـ' 'شord (/shisheh/) in Persian. Among the 3 cases of occurrence of the word 'شيشّ' (/shisheh/) in museum captions, 1 case included the accurate English translation. This means that $33.3 \%$ of the translations were accurate.

\section{3. 'كاسه' (/kaaseh/)}

Table 13 below illustrates the number of matches $(+)$, mismatches (-) and partial matches (0) for the Persian word 'كاسه' (/kaaseh/) and its suggested English equivalents.

Table13. The Scores of Each Sign for the English Equivalents of the Persian Word 'كاسه' (/kaaseh/)

\begin{tabular}{|c|c|c|c|c|}
\hline Museum Names & Words & + & - & 0 \\
\hline 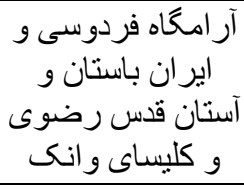 & Bowl & 2 & 0 & 2 \\
\hline كليران باستان و وانك & Vessel & 0 & 0 & 4 \\
\hline كليساى و انك & Jar & 0 & 0 & 4 \\
\hline
\end{tabular}


According to Table13, and based on the highest score of the word 'bowl', 'bowl' is the most accurate English equivalent for the word 'كاسا' (كاس '/kaaseh/) in Persian. Among the 7 cases of occurrence of the word 'كاس山' (/kaaseh/) in museum captions, 3 cases included the accurate English translation. This means that $42.8 \%$ of the translations were accurate.

\section{4. 'قَّمدان' (/ghalamdaan/)}

Table 14 below illustrates the number of matches $(+)$, mismatches (-) and partial matches (0) in the case of the Persian word 'قلمدان' (/ghalamdaan/) and its suggested English equivalents.

Table 14. The Scores of Each Sign for the English Equivalents of the Persian Word 'قلمدان' (/ghalamdaan/)

\begin{tabular}{|c|c|c|c|c|}
\hline $\begin{array}{c}\text { Museum } \\
\text { Names }\end{array}$ & Words & + & - & 0 \\
\hline \hline جهارفصل & Pen box & 3 & 0 & 0 \\
\hline آر امخاه فردوسى & Pen case & 0 & 3 & 0 \\
\hline
\end{tabular}

The phrase 'pen box' has the highest score in + sign and is actually totally congruent with semantic features of 'قلمدان' (/ghalamdaan/) in Persian. So, 'pen box' is suggested as the most accurate equivalent for 'قلمدان' (/ghalamdaan/) in Persian. Among the 2 cases of occurrence of the word 'قلمدان' (/ghalamdaan/) in museum captions, 1 case included the accurate English translation. This means that $50 \%$ of the translations were accurate.

\section{5. 'لعاب' (/laab/)}

Table 15 below illustrates the number of matches $(+)$, mismatches (-) and partial matches (0) for the Persian word 'لعاب' (/laab/) and its 
224 Componential Analysis of Equivalents

suggested English equivalents.

Table15. The Scores of Each Sign for the English Equivalents of the Persian Word ‘لعاب' (/laab/)

\begin{tabular}{|c|c|c|c|c|}
\hline Museum Names & Words & + & 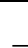 & 0 \\
\hline 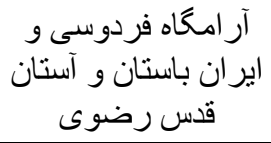 & Glaze & 4 & 0 & 0 \\
\hline آر امكاه فردوسى و & Lustre & 1 & 0 & 3 \\
\hline
\end{tabular}

According to Table 15, and based on the highest score of the word 'glaze', the word 'glaze' is the most accurate English equivalent for 'لعاب' (/laab/) in Persian. Among the 5 cases of occurrence of the word 'لعاب' (/laab/) in museum captions, 3 cases included the accurate English translation. This means that $60 \%$ of the translations were accurate.

\section{6. 'طلاكوب' (/talaakoob/)}

Table 16 below illustrates the number of matches $(+)$, mismatches (-) and partial matches (0) for the Persian word 'طلاكوب' (/talaakoob/) and its suggested English equivalents.

Table16. The Scores of Each Sign for the English Equivalents of the Persian Word 'طلاكوب' (/talaakoob/)

\begin{tabular}{|c|c|c|c|c|}
\hline $\begin{array}{c}\text { Museum } \\
\text { Names }\end{array}$ & Words & + & - & 0 \\
\hline \hline ايران باستان & Gilded & 1 & 1 & 0 \\
\hline $\begin{array}{c}\text { رانتان قدسى } \\
\text { رضوى }\end{array}$ & $\begin{array}{c}\text { Inlaid with } \\
\text { gold }\end{array}$ & 2 & 0 & 0 \\
\hline
\end{tabular}


According to Table 16, and based on the highest score of the phrase 'inlaid with gold', the most accurate English equivalents for

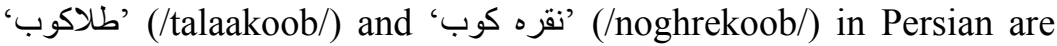
'inlaid with gold' and 'inlaid with silver', respectively. Among the 2 cases of occurrence of the word 'طلاكوب' (/talaakoob/) in museum captions, 1 case included the accurate English translation. This means that $50 \%$ of the translations were accurate.

\section{7. 'كوزه' (/koozeh/)}

Table 17 below illustrates the number of matches $(+)$, mismatches (-) and partial matches (0) for the Persian word 'كوزه' (/koozeh/) and its suggested English equivalents.

Table17. The Scores of Each Sign for the English Equivalents of the Persian Word 'كوزه' (/koozeh/)

\begin{tabular}{|c|c|c|c|c|}
\hline $\begin{array}{l}\text { Museum } \\
\text { Names }\end{array}$ & Words & + & - & 0 \\
\hline رضوى و آستان قدسينه & Jug & 2 & 0 & 2 \\
\hline جهار فصل & Bottle & 3 & 0 & 1 \\
\hline كليساى و انك و جهلتون & Jar & 2 & 0 & 2 \\
\hline كليساى وآبشينه و انك & Pot & 0 & 1 & 3 \\
\hline
\end{tabular}

According to Table 17, and based on the highest score of the word 'bottle', the most accurate English equivalent for the word ' كوزه، (/koozeh/) in Persian is the word 'bottle' in English. Among the 7 cases of occurrence of the word 'كوزه' (/koozeh/) in museum captions, 2 cases included the accurate English translation. This means that $28.5 \%$ of the translations were accurate. 


\section{8. 'خاتم كارى' (/khaatamkaari/)}

Table 18 below illustrates the number of matches $(+)$, mismatches (-) and partial matches (0) in the case of the Persian word 'خاتم كارى' (/khaatamkaari/) and its suggested English equivalents.

Table 18. The Scores of Each Sign for the English Equivalents of the Persian Phrase 'خانت كارى' (/khaatamkaari/)

\begin{tabular}{|c|c|c|c|c|}
\hline $\begin{array}{c}\text { Museum } \\
\text { Names }\end{array}$ & Words & + & - & 0 \\
\hline \hline آرامخاه فردوسى & Cachet & 0 & 4 & 0 \\
\hline- & Inlaying & 3 & 0 & 1 \\
\hline
\end{tabular}

The word 'cachet' which is suggested by a museum is absolutely irrelevant to the meaning and process of 'خاتم كارى' (/khaatamkaari/) in Persian. The word 'inlaying' which is suggested by Ettinghausen (1972: 305) has more matches in semantic features with those of 'خاتم كارى' (khaatamkaari/) in Persian. So, the word 'inlaying' and

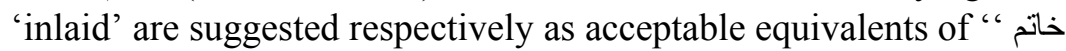
كارى' (/khaatamkaari/)' and '“خاتم كارى شده' (/khaatamkaari shode/)' in Persian. The only one case of occurrence of the word 'خارى' 'خارى' (/khaatamkaari/) in museum captions was wrong in translation. This means that the English translation was not accurate.

\section{9. 'بيله سوز (/pihsooz/)}

Table 19 below illustrates the number of matches $(+)$, mismatches (-) and partial matches (0) in the case of the Persian word 'بيّه سوز (/pihsooz/) and its suggested English equivalents. 
Table 19. The Scores of Each Sign for the English Equivalents of the Persian Word 'بيه سوز' (/pihsooz/)

\begin{tabular}{|c|c|c|c|c|}
\hline Museum Names & Words & + & & 0 \\
\hline آر امخاه فردوسى & Lamp & 2 & 0 & 3 \\
\hline كليران باستان و وانى & Oil lamp & 4 & 0 & 1 \\
\hline كلبساى و انكى & Tallow lamp & 3 & 0 & 2 \\
\hline رآستان قدى & $\begin{array}{l}\text { Tallow } \\
\text { burner }\end{array}$ & 1 & 0 & $\overline{4}$ \\
\hline
\end{tabular}

According to Table 19, and based on the highest score of the phrase 'oil lamp', 'oil lamp' is the most accurate equivalent for 'يبه 'سوز'/pihsooz/) in Persian. Among the 5 cases of occurrence of the word 'بيه سوز' (/pihsooz/) in museum captions, 2 cases included the accurate English translation. This means that $40 \%$ of the translations were accurate.

\subsection{0. 'قتديل' (/ghandil/)}

Table 20 below illustrates the number of matches $(+)$, mismatches (-) and partial matches (0) in the case of the Persian word 'قنديل' (/ghandil/) and its suggested English equivalents.

Table 20. The Scores of Each Sign for the English Equivalents of the Persian Word 'قنديل' (/ghandil/)

\begin{tabular}{|c|c|c|c|c|}
\hline $\begin{array}{c}\text { Museum } \\
\text { Names }\end{array}$ & Words & + & - & 0 \\
\hline $\begin{array}{c}\text { آستان قدسى } \\
\text { رآنوىن }\end{array}$ & Lantern & 2 & 0 & 1 \\
\hline & Mosque lamp & 0 & 3 & 0 \\
\hline
\end{tabular}

As lantern has the most matches in semantic features with those of 'قنديل' (/ghandil/) in Persian and since it is also suggested by 
Fehervari (1976: plate 33) as the English equivalent of what is called 'قنديل' (/ghandil/) in Persian, it is an appropriate English equivalent for 'قنديل' (/ghandil/) in Persian. Among the 2 cases of occurrence of the word 'قنديل' (/ghandil/) in museum captions, 1 case included the accurate English translation. This means that $50 \%$ of the translations were accurate.

It is thus to be noted that on the basis of the above information, the English words 'jug', 'glass', 'bowl', 'pen-box', 'glaze', 'inlaid with gold', 'bottle', 'inlaid', 'oil lamp' and 'lantern' are respectively the most accurate English equivalents for the Persian words '

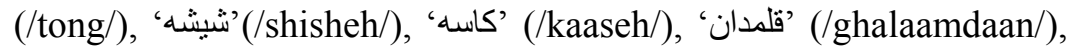

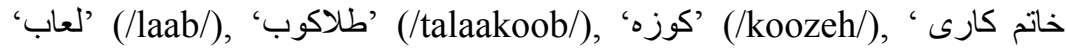

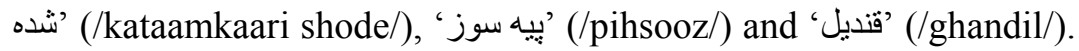
In other words, $39.74 \%$ of English translations are accurate. This means that $60.26 \%$ of the English translations are inaccurate. Since most of the English translations of the Persian texts used in museum captions of historical objects are semantically inaccurate, a major revision of them by museum translators is definitely indispensible.

A final word is that English, as an international language, is the language of introducing the majority of places and museum objects to tourists all over the world. In Iran, English is the most common second language in introducing historical and ancient places and museum objects to tourists. Thus, accurate translation of the names, materials and type of decorations of ancient and historical stuff from Persian into English and other languages is a challenging matter. This is why the findings of the present research are of paramount importance. These findings can be examined in other museums with other objects in other cities and countries. Also, in line with these findings, other pieces of research can be conducted, for instance, on the accuracy of English translation of the names of different colours used in Iranian and other nations' carpets exhibited in carpet museums around the world. Another topic for research can be the study of the tourists' perceptions of the English translations of the 
captions for historical objects in museums in different countries.

\section{References}

Amid, H. 1981. Amid Dictionary. Tehran: Amirkabir Publications. Bell, T. R. 1991. Translation and Translating: Theory and Practice. London \& New York: Longman.

1976. British Museum Guide. Worcester \& London: British Museum Publications Limited.

Ettinghausen, R. 1972. Islamic Art. New York: The Metropolitan Museum of Art.

Fehervari, G. 1973. Islamic Pottery: A Comprehensive Study Based on the Barlow Collection. London: Faber and Faber.

Fehervari, G. 1976. Islamic Metalwork of the English to the Fifteenth Century in Keir Collection. London: Faber and Faber.

Fournier, R. 2000. Illustrated Dictionary of Practical Pottery. London: A \& C Black.

Insulander, E. 2007. The Exhibition as a Multimodal Pedagogical Text. Presented at NaM Making National Museums Program, Setting the frames, 26-28 February, Norrköping Sweden. Available at URL < http://www.ep.liu.se/ecp/022/011/index.html.>

James, C. 1980. Contrastive Analysis. New York: Longman

Kress, G. \& van Leeuwen, T. 1996/2006. Reading Images: The Grammar of Visual Design. London \& New York: Routledge.

Kress, G. \& van Leeuwen, T. 2001. Multimodal Discourse: The Modes and Media of Contemporary Communication. London: Arnold.

Kress, G. 2003. Literacy in the New Media Age. London \& New York: Routledge.

Larson, M. L. 1984. Meaning-based Translation: A Guide to CrossLanguage Equivalence. London: University Press of America. 2010. Loghatnaameh Dehkhoda Persian Dictionary. Available 
at URL <http://www.loghatnaameh.com/.> Massod, E. 1997. Dictionary of Ceramics. Tehran: Navid Shiraz. 2010. Merriam-Webster Online Dictionary.

Available at URL $<$ http://www.merriam-webster.com/dictionary $>$. Microsoft Encarta and Student Program Manager 2006. Encarta Dictionaries. [Computer Software]. USA.

Mirhadi, B. 2006. Encyclopedia of Ceramic, Glass, Building Material (English-Persian-German). Tehran: Ganjehonar. 2010. Moin Persian Dictionary. Available at URL

$<\mathrm{http}$ ://www.rismoon.com/moeenletterindex-fa.html.>

Newmark, P. 1988. A Textbook of Translation. London: PrenticeHall International.

Palumbo, G. 2009. Key Terms in Translation Studies. London: Continuum.

Pope, A. J. 1962. Ancient Glass in the Freer Gallery of Art. Washington D.C. and New York: Smithsonian.

Remael, A. 2001. Some Thoughts on the Study of Multimodal and Multimedia Translation. In G. Yves and G. Henrik (eds.), (Multi)media Translation: Concepts, Practices and Research, 13-21. Philadelphia: John Benjamin.

Saeed, I. J. 2003. Semantics. Oxford: Blackwell.

Snell-Hornby, M. 2006. The Turns of Translation Studies: New Paradigms or Shifting Viewpoints? Amsterdam \& Philadelphia: John Benjamin. 


\section{Appendices}

\section{Persian words and their definitions in three Persian monolingual dictionaries:}

\section{'تنع' (/tong/)}

\begin{tabular}{|c|c|}
\hline فر هنح دهخدا & 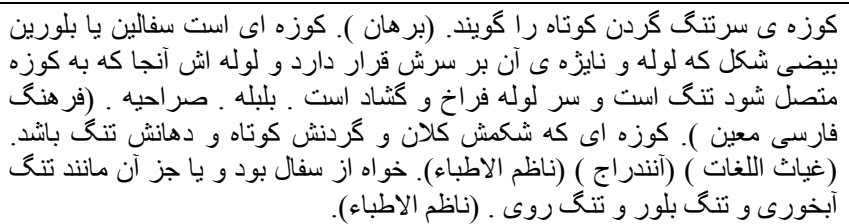 \\
\hline فر هنگ معين & كوزثد اي از جنس سفال با بلور كه قست بايين آن بزرك و بالاى آن تنى و باريك \\
\hline فر هنگ عميد & 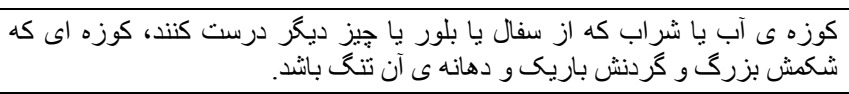 \\
\hline
\end{tabular}

'شيشه، (/shisheh/)

\begin{tabular}{|c|c|}
\hline فر هنگ دهخدا & 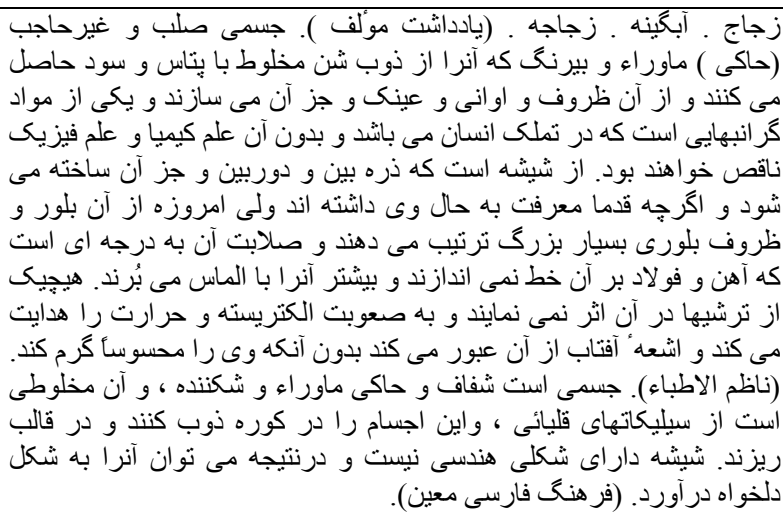 \\
\hline فر هنى معين & 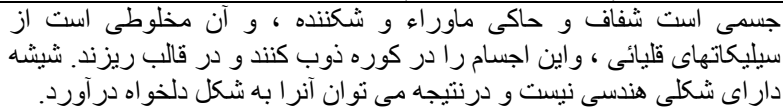 \\
\hline فر هنى عميد & 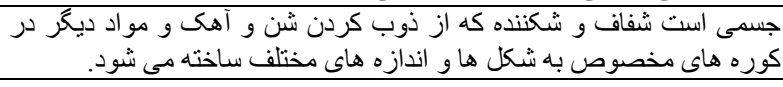 \\
\hline
\end{tabular}


232 Componential Analysis of Equivalents

\section{'كاسهי' (/kaaseh/)}

\begin{tabular}{|c|c|}
\hline فر هنى دهخدا & 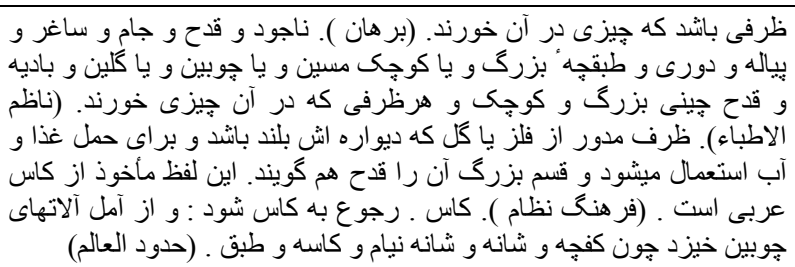 \\
\hline فر هنگ معين & 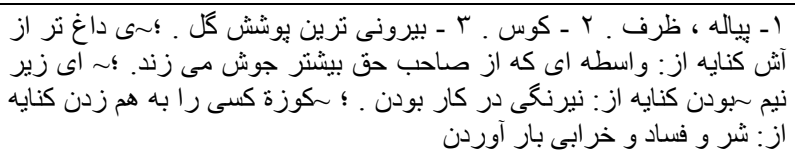 \\
\hline فر هنح عميد & سفالى يا جا \\
\hline
\end{tabular}

\section{"قّمدان' (/ghalamdaan/)}

\begin{tabular}{|c|c|}
\hline فر هنـ دهخدا & 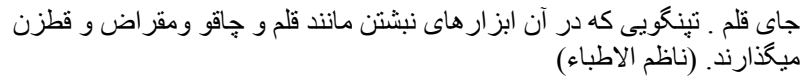 \\
\hline فر هنگ معين & بهم فشرده ساخته مهى شود. آنه مركب از دو قطعه كه روكش ديكرى است. از مقوا با كاغذ \\
\hline فرهنى عميد & 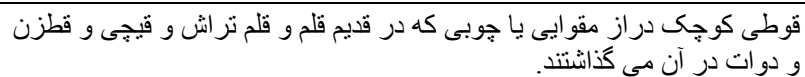 \\
\hline
\end{tabular}

\section{'لعاب؛ (/laab/)}

\begin{tabular}{|c|c|}
\hline فر هنگ دهخدا & 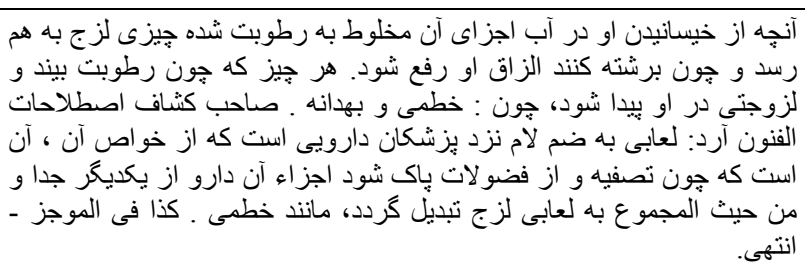 \\
\hline فر هنگ معين & 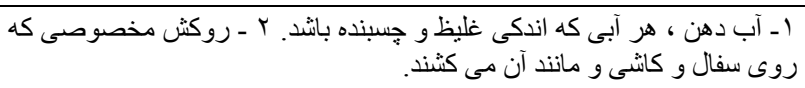 \\
\hline فر هنگ عميد & هر آبى كه اندكى غليظ و جسبنده باشد. \\
\hline
\end{tabular}


Razieh Shivaei \& Hossein Vahid Dastjerdi 233

'طلاكوب' (/talaakoob/)

\begin{tabular}{|c|c|}
\hline فر هنى دهخدا & آنكه ورق هاى طلا و نقره را بسازد. \\
\hline فر هنگ معين & آنكه ورق هاى طلا و نقره ر ا مى سازد. \\
\hline فر هنى عميد & كو بيدن ورق هاى نارك طلا بر جيزى \\
\hline
\end{tabular}

\section{'كوزه، (/koozeh/)}

\begin{tabular}{|c|c|}
\hline فر هنگ دهخدا & 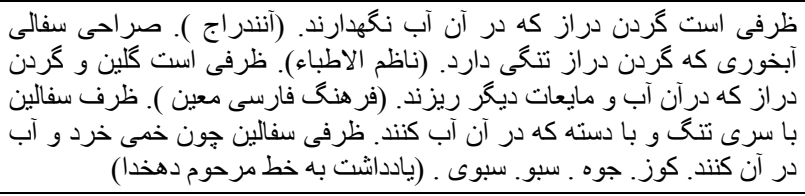 \\
\hline فر هنگ معين & 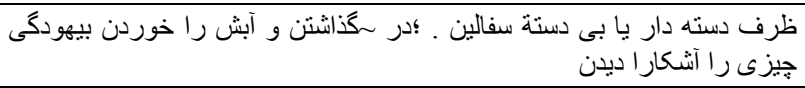 \\
\hline فر هنگ عميد & هـ دار يا بى د \\
\hline
\end{tabular}

\section{'خاتم كارى (/khatamkari/)}

\begin{tabular}{|c|c|}
\hline فر هنگ دهخدا & 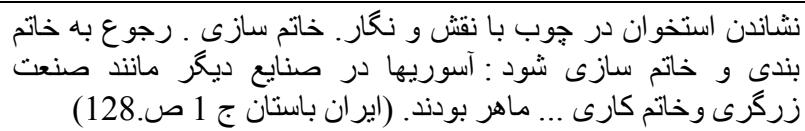 \\
\hline فر هنگ معين & 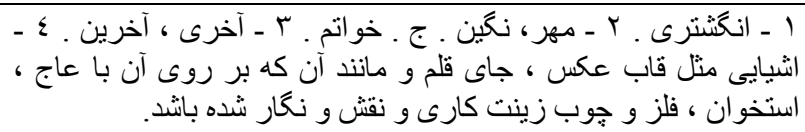 \\
\hline فر هنگ عميد & 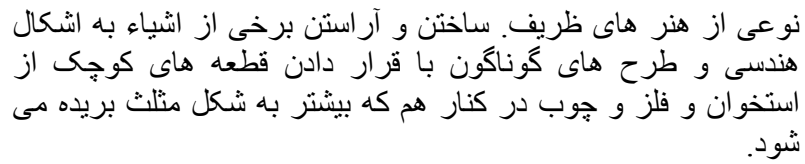 \\
\hline
\end{tabular}

\section{'بيه سوز' (/pihsooz/)}

\begin{tabular}{|c|c|}
\hline فر هنگ دهخدا & 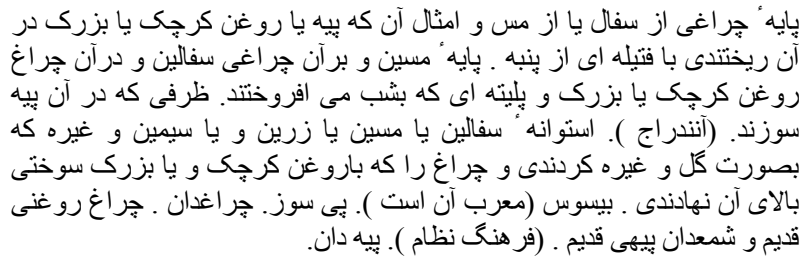 \\
\hline
\end{tabular}




\begin{tabular}{|c|c|}
\hline فر هنگ معين & 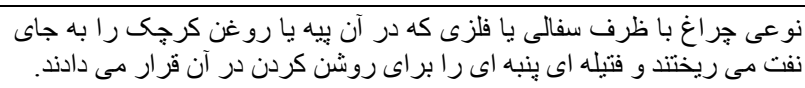 \\
\hline فر هنگ عميد & 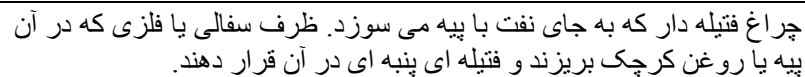 \\
\hline
\end{tabular}

\section{'قنديل' (/ghandil/)}

\begin{tabular}{|c|c|}
\hline فر هنگ دهخدا & 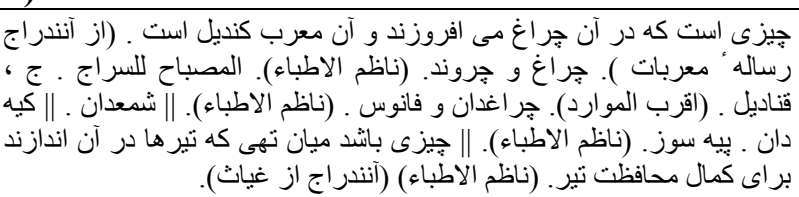 \\
\hline فر هنگ معين & شمع و جر اغ . ج ـ قناديل \\
\hline فر هنى عميد & جر اغ آويز، مشعل، كه از سقف آويزان مى كنند. \\
\hline
\end{tabular}

\section{Suggested English equivalents and their English definitions in five English monolingual dictionaries:}

\section{'carafe'}

\begin{tabular}{|c|c|}
\hline Oxford & A glass bottle for water or wine at a table, in a bed room, etc. \\
\hline Encarta & $\begin{array}{l}\text { Container for serving drinks: a container with a wide } \\
\text { cylindrical base, a narrow neck, and a flared open top, } \\
\text { usually made of glass and used to serve liquids, especially } \\
\text { wine or water at table. }\end{array}$ \\
\hline Webster & $\begin{array}{l}\text { 1: a bottle with a flaring (wide) lip used to hold beverages } \\
\text { and especially wine } \\
\text { 2: a usually glass container used to hold and serve coffee. }\end{array}$ \\
\hline Cambridge & $\begin{array}{l}\text { A tall glass container with a wide round bottom for serving } \\
\text { wine or water in a restaurant, or the amount contained in it. }\end{array}$ \\
\hline Longman & $\begin{array}{l}\text { A glass container with a wide neck, used for serving wine or } \\
\text { water at meals. }\end{array}$ \\
\hline
\end{tabular}

\section{'pitcher'}

\begin{tabular}{|c|l|}
\hline Oxford & $\begin{array}{l}\text { A large usu. earthenware vessel with a handle and usu. a lip, } \\
\text { for holding and pouring out liquids; a jug; a jug-shaped or } \\
\text { vase-shaped vessel. }\end{array}$ \\
\hline
\end{tabular}




\begin{tabular}{|c|l|}
\hline Encarta & $\begin{array}{l}\text { Single-handled jug: a container for liquids with a single } \\
\text { handle and a lip or spout for pouring. }\end{array}$ \\
\hline Webster & $\begin{array}{l}\text { a container for holding and pouring liquids that usually has a } \\
\text { lip or spout and a handle. }\end{array}$ \\
\hline Cambridge & $\begin{array}{l}\text { a large container with a wide round base, straight sides and a } \\
\text { narrow opening at the top, used in the past for holding water } \\
\text { or another liquid. }\end{array}$ \\
\hline Longman & $\begin{array}{l}\text { American English a container for holding and pouring a } \\
\text { liquid, with a handle and a shaped part to help the liquid } \\
\text { flow out. } \\
\text { British English a large clay container with two handles, used } \\
\text { in the past for holding and pouring a liquid. }\end{array}$ \\
\hline
\end{tabular}

\section{'ewer'}

\begin{tabular}{|c|l|}
\hline Oxford & $\begin{array}{l}\text { A jug with a wide mouth, esp. a water-jug of the kind } \\
\text { formerly used in bedrooms. }\end{array}$ \\
\hline Encarta & $\begin{array}{l}\text { Large jug with a wide spout: a large jug or pitcher with a } \\
\text { wide spout. }\end{array}$ \\
\hline Webster & A vase-shaped pitcher or jug. \\
\hline Cambridge & - \\
\hline Longman & - \\
\hline
\end{tabular}

\section{'jug'}

\begin{tabular}{|c|l|}
\hline Oxford & $\begin{array}{l}\text { A deep vessel for holding liquids, usu. with a cylindrical, } \\
\text { tapering, or swelling body, having a handle and often a spout } \\
\text { or lip for pouring. Also US, a large jar with a narrow mouth. }\end{array}$ \\
\hline Encarta & $\begin{array}{l}\text { pouring container: a deep container for liquids that has a } \\
\text { handle and has its rim shaped into a lip or spout for pouring } \\
\text { North America large container for liquids: a large container } \\
\text { for liquids, typically of earthenware or glass, with a handle } \\
\text { and a narrow mouth usually closed with a cork }\end{array}$ \\
\hline Webster & $\begin{array}{l}\text { A large deep usually earthenware or glass container with a } \\
\text { narrow mouth and a handle }\end{array}$ \\
\hline Cambridge & $\begin{array}{l}\text { UK a container for holding liquids which has a handle and a } \\
\text { shaped opening at the top for pouring. } \\
\text { US a large round container for liquids which has a flat base, a } \\
\text { handle and a very narrow raised opening at the top for } \\
\text { pouring. }\end{array}$ \\
\hline
\end{tabular}




\begin{tabular}{|l|l|}
\hline Longman & $\begin{array}{l}\text { British English a container with a wide curved opening at the } \\
\text { top and a handle, used especially at meals for pouring } \\
\text { liquids [= pitcher American English] }\end{array}$ \\
\hline
\end{tabular}

\section{'bottle'}

\begin{tabular}{|c|l|}
\hline Oxford & $\begin{array}{l}\text { A narrow-necked vessel, orig. of leather, now usu. of glass } \\
\text { or plastic, for storing liquids. }\end{array}$ \\
\hline Encarta & $\begin{array}{l}\text { Container for liquids: a container for liquids, usually made } \\
\text { of glass or plastic, with a narrow neck and no handle. }\end{array}$ \\
\hline Webster & $\begin{array}{l}\text { A rigid or semi-rigid container typically of glass or plastic } \\
\text { having a comparatively narrow neck or mouth and usually } \\
\text { no handle. }\end{array}$ \\
\hline Cambridge & $\begin{array}{l}\text { A container for liquids, usually made of glass or plastic, with } \\
\text { a narrow neck. }\end{array}$ \\
\hline Longman & $\begin{array}{l}\text { A container with a narrow top for keeping liquids in, usually } \\
\text { made of plastic or glass. }\end{array}$ \\
\hline
\end{tabular}

\section{'frit'}

\begin{tabular}{|c|l|}
\hline Oxford & $\begin{array}{l}1 \text { A calcined mixture of silica and fluxes, which can be } \\
\text { melted to make glass. } \\
\mathbf{2} \text { A vitreous composition from which soft porcelain, enamel, } \\
\text { etc., are made. }\end{array}$ \\
\hline Encarta & $\begin{array}{l}\text { Basic materials for glass: the basic materials from which } \\
\text { glass, pottery glazes, or enamels are made, when they are in } \\
\text { a partially bonded state at the beginning of the } \\
\text { manufacturing process. }\end{array}$ \\
\hline Webster & $\begin{array}{l}\mathbf{1} \text { the calcined or partly fused materials of which glass is made. } \\
\mathbf{2} \text { any of various chemically complex glasses used ground } \\
\text { especially to introduce soluble or unstable ingredients into } \\
\text { glazes or enamels. }\end{array}$ \\
\hline Cambridge & $-\quad$ \\
\hline Longman & - \\
\hline
\end{tabular}




\section{'glass'}

\begin{tabular}{|c|l|}
\hline Oxford & $\begin{array}{l}\text { A substance, usu. transparent, lustrous, hard, and brittle, made } \\
\text { by fusing soda or potash or both with other ingredients. }\end{array}$ \\
\hline Encarta & $\begin{array}{l}\text { Transparent solid substance: a hard, usually transparent } \\
\text { substance that shatters easily. Source: sand melted in } \\
\text { combination with other oxides such as lime or soda. Use: } \\
\text { windows, bottles, lenses. }\end{array}$ \\
\hline Webster & $\begin{array}{l}\text { Any of various amorphous materials formed from a melt by } \\
\text { cooling to rigidity without crystallization: as a usually } \\
\text { transparent or translucent material consisting typically of a } \\
\text { mixture of silicates. }\end{array}$ \\
\hline Cambridge & $\begin{array}{l}\text { A hard transparent material which is used to make windows, } \\
\text { bottles and other objects. }\end{array}$ \\
\hline Longman & $\begin{array}{l}\text { A transparent solid substance used for making windows, } \\
\text { bottles etc. }\end{array}$ \\
\hline
\end{tabular}

\section{'ceramic'}

\begin{tabular}{|c|l|}
\hline Oxford & $\begin{array}{l}\text { Of or relating to (the art of) pottery; designating or pertaining } \\
\text { to hard brittle substances produced by the process of strong } \\
\text { heating of clay etc. }\end{array}$ \\
\hline Encarta & $\begin{array}{l}\text { Hard fired clay: a hard brittle heat-resistant material made } \\
\text { by firing a mixture of clay and chemicals at high } \\
\text { temperature. }\end{array}$ \\
\hline Webster & $\begin{array}{l}\text { Of or relating to the manufacture of any product (as } \\
\text { earthenware, porcelain, or brick) made essentially from a } \\
\text { nonmetallic mineral (as clay) by firing at a high } \\
\text { temperature; also: of' or relating to such a product. }\end{array}$ \\
\hline Cambridge & $\begin{array}{l}\text { The objects produced by shaping and heating clay, especially } \\
\text { when considered as art. }\end{array}$ \\
\hline Longman & $\begin{array}{l}\text { The art of making pots, bowls, TILEs etc, by shaping pieces of } \\
\text { clay and baking them until they are hard. }\end{array}$ \\
\hline
\end{tabular}

\section{'bowl'}

\begin{tabular}{|c|l|}
\hline Oxford & $\begin{array}{l}\text { A vessel, usu. hemispherical or nearly so, to hold liquids or } \\
\text { food; a basin. }\end{array}$ \\
\hline Encarta & $\begin{array}{l}\text { Round container: an open container, usually round in shape } \\
\text { and wider than it is deep, typically used for holding food and } \\
\text { liquids. }\end{array}$ \\
\hline
\end{tabular}




\begin{tabular}{|c|l|}
\hline Webster & $\begin{array}{l}\text { A concave usually nearly hemispherical vessel; specifically: } \\
\text { a drinking vessel (as for wine) }\end{array}$ \\
\hline Cambridge & $\begin{array}{l}\text { A round container that is open at the top and is deep enough } \\
\text { to hold fruit, sugar, etc. }\end{array}$ \\
\hline Longman & $\begin{array}{l}\text { A wide round container that is open at the top, used to hold } \\
\text { liquids, food, flowers etc. }\end{array}$ \\
\hline
\end{tabular}

'vessel'
\begin{tabular}{|c|l|}
\hline Oxford & $\begin{array}{l}\text { 1. Dishes or utensils for domestic or table use; spec. these } \\
\text { made of gold or silver, plate. Long obs. exc. dial. }\end{array}$ \\
\hline Encarta & $\begin{array}{l}\text { A hollow container or receptacle for a liquid etc., esp. a } \\
\text { domestic or table utensil, as a cup, bottle, pot, bowl, or dish. }\end{array}$ \\
\hline Webster & $\begin{array}{l}\text { Receptacle: a hollow receptacle, especially one that is used as } \\
\text { a container for liquids. }\end{array}$ \\
\hline Cambridge & A comething. \\
\hline Longman & A container for holding liquids. \\
\hline
\end{tabular}

\section{'jar'}

\begin{tabular}{|c|l|}
\hline Oxford & $\begin{array}{l}\text { A usu. cylindrical container of glass, earthenware, or stoneware } \\
\text { with no spout or handle (or with two handles). Orig., a large } \\
\text { earthenware vessel for holding water, oil, wine, etc. }\end{array}$ \\
\hline Encarta & $\begin{array}{l}\text { Storage container: a cylindrical container, usually one that } \\
\text { has a wide mouth and a lid but no spout, typically made of } \\
\text { glass, plastic, or earthenware. }\end{array}$ \\
\hline Webster & A wide mouthed container made typically of earthenware or glass. \\
\hline Cambridge & $\begin{array}{l}\text { A glass or clay container, with a wide opening at the top and } \\
\text { sometimes a fitted lid, which is usually used for storing food. }\end{array}$ \\
\hline Longman & $\begin{array}{l}\text { A container made of clay, stone etc used especially in the } \\
\text { past for keeping food or drink in }\end{array}$ \\
\hline
\end{tabular}




\section{'glaze'}

\begin{tabular}{|c|l|}
\hline Oxford & $\begin{array}{l}\text { The vitreous substance fixed by fusion to the surface of } \\
\text { pottery etc. and forming an impervious decorative coating. }\end{array}$ \\
\hline Encarta & $\begin{array}{l}\text { Cover pottery with finish like glass: to put a clear or } \\
\text { colored coating on a ceramic object and fire it in a kiln, in } \\
\text { order to fix the coloration, make it watertight, or give it a } \\
\text { shiny appearance. }\end{array}$ \\
\hline Webster & $\begin{array}{l}\text { A mixture mostly of oxides (as silica and alumina) applied to } \\
\text { the surface of ceramic wares to form a moisture-impervious } \\
\text { and often lustrous or ornamental coating }\end{array}$ \\
\hline Cambridge & $\begin{array}{l}\text { To make a surface shiny by putting a liquid substance onto it } \\
\text { and leaving it or heating it until it dries. }\end{array}$ \\
\hline Longman & $\begin{array}{l}\text { A liquid that is used to cover plates, cups etc made of clay to } \\
\text { give them a shiny surface. }\end{array}$ \\
\hline
\end{tabular}

\section{'Iuster'}

\begin{tabular}{|c|l|}
\hline Oxford & $\begin{array}{l}\text { An iridescent metallic decorative surface on ceramics; the } \\
\text { glaze used to produce this; gen. any shining or reflective } \\
\text { finish (as on a photograph etc.). }\end{array}$ \\
\hline Encarta & $\begin{array}{l}\text { Glaze on pottery: an opalescent metallic glaze on pottery, } \\
\text { especially porcelain. }\end{array}$ \\
\hline Webster & $\begin{array}{l}\text { A glow of reflected light: sheen; specifically: the appearance of } \\
\text { the surface of a mineral dependent upon its reflecting qualities. }\end{array}$ \\
\hline Cambridge & The brightness that a shiny surface has. \\
\hline Longman & An attractive shiny appearance. \\
\hline
\end{tabular}

\section{'gilded'}

\begin{tabular}{|c|l|}
\hline Oxford & $\begin{array}{l}\text { That has been gilded; spec. overlaid wholly or partially with } \\
\text { a thin coating of gold. }\end{array}$ \\
\hline Encarta & $\begin{array}{l}\text { Covered with gilt: covered with a thin layer of gold or a } \\
\text { substance that looks like gold. }\end{array}$ \\
\hline Webster & To overlay with or as if with a thin covering of gold. \\
\hline Cambridge & $\begin{array}{l}\text { To cover a surface with a thin layer of gold or a substance } \\
\text { that looks like gold. }\end{array}$ \\
\hline Longman & $\begin{array}{l}\text { To cover something with a thin layer of gold or with } \\
\text { something that looks like gold. }\end{array}$ \\
\hline
\end{tabular}




\begin{tabular}{|c|c|}
\hline Oxford & $\begin{array}{l}\text { Fit (a thing) with a substance of a different kind embedded in } \\
\text { its surface; diversify by the insertion of another material in a } \\
\text { decorative design. }\end{array}$ \\
\hline Encarta & $\begin{array}{l}\text { set something into surface: to set pieces of material such as } \\
\text { wood, ivory, or stone into previously cut slots in a surface to } \\
\text { form a decorative pattern } \\
\text { decorate something with inlaid design: to decorate } \\
\text { something such as a piece of furniture by setting pieces of } \\
\text { wood, stone, ivory, or other material into its surface }\end{array}$ \\
\hline Webster & $\begin{array}{l}\text { Set into a surface in a decorative design }<\text { tables with inlaid } \\
\text { marble }>\text {. Decorated with a design or material set into a } \\
\text { surface }<\text { a table with an inlaid top }>\text {. }\end{array}$ \\
\hline Cambridge & A decorative pattern put into the surface of an object \\
\hline Longman & $\begin{array}{l}\text { An inlaid box, table, floor etc has little pieces of another } \\
\text { material set into its surface for decoration. }\end{array}$ \\
\hline
\end{tabular}

'pot'

\begin{tabular}{|c|l|}
\hline Oxford & $\begin{array}{l}\text { A deep rounded or cylindrical vessel, usu. made of earthenware, } \\
\text { metal, or glass, and used for holding liquid or solid } \\
\text { substances or for various other purposes. }\end{array}$ \\
\hline Encarta & $\begin{array}{l}\text { container for cooking: a container made of metal, pottery, } \\
\text { or glass that is usually cylindrical and watertight with an } \\
\text { open top and sometimes a lid, used especially for cooking or } \\
\text { storage }\end{array}$ \\
\hline Webster & $\begin{array}{l}\text { A usually rounded metal or earthen container used chiefly } \\
\text { for domestic purposes (as in cooking or for holding liquids } \\
\text { or growing plants) } \\
\text { Clay object: a dish or container made from clay, especially } \\
\text { one of artistic or historical interest. }\end{array}$ \\
\hline Cambridge & $\begin{array}{l}\text { Any of various types of container, usually round, especially } \\
\text { one used for cooking. } \\
\text { UK any of different types of containers, with or without a } \\
\text { lid, especially for storing food or liquids }\end{array}$ \\
\hline Longman & $\begin{array}{l}\text { A container used for cooking which is round, deep, and } \\
\text { usually made of metal. }\end{array}$ \\
\hline
\end{tabular}




\begin{tabular}{|c|l|}
\hline 'cachet' \\
\hline Oxford & $\begin{array}{l}\text { 1 A seal for letters, documents, etc. Now rare or obs. } \\
\mathbf{2} \text { A characteristic or distinguishing mark; a characteristic } \\
\text { feature or quality conferring prestige or distinction; high } \\
\text { status. }\end{array}$ \\
\hline Encarta & $\begin{array}{l}\mathbf{1} \text { quality that attracts admiration: a quality of distinction } \\
\text { and style that people admire and approve of } \\
\mathbf{2} \text { official mark: an official seal or stamp on a letter or other } \\
\text { document }\end{array}$ \\
\hline Webster & $\begin{array}{l}\text { a design or inscription on an envelope to commemorate a } \\
\text { postal or philatelic event }\end{array}$ \\
\hline Cambridge & $\begin{array}{l}\text { a quality which marks someone or something as special and } \\
\text { worth respect and admiration }\end{array}$ \\
\hline Longman & $\begin{array}{l}\text { if something has cachet, people think it is very good or } \\
\text { specia }\end{array}$ \\
\hline
\end{tabular}

'lamp'
\begin{tabular}{|c|l|}
\hline Oxford & $\begin{array}{l}\text { A vessel in which oil is burnt at a wick to provide } \\
\text { illumination. Now gen., (a device, often consisting of a } \\
\text { holder and shade, designed to hold or enclose) a source of } \\
\text { artificial illumination, as a candle, a gas-jet, or (usu.) an } \\
\text { electric bulb. Also, a device producing infrared, ultraviolet, } \\
\text { or other radiation, esp. for therapeutic purposes. }\end{array}$ \\
\hline Encarta & $\begin{array}{l}\text { Device producing light: a device that burns oil, gas, or wax } \\
\text { to produce light. }\end{array}$ \\
\hline Webster & $\begin{array}{l}\text { any of various devices for producing light or sometimes } \\
\text { heat: as (1) : a vessel with a wick for burning an inflammable } \\
\text { liquid (as oil) to produce light (2) : a glass bulb or tube that } \\
\text { emits light produced by electricity (as an incandescent light } \\
\text { bulb or fluorescent lamp) }\end{array}$ \\
\hline Cambridge & $\begin{array}{l}\text { a device for giving light, especially one that has a covering } \\
\text { or is contained within something }\end{array}$ \\
\hline Longman & an object that produces light by using electricity, oil, or gas \\
\hline
\end{tabular}


'tallow'

\begin{tabular}{|c|l|}
\hline Oxford & $\begin{array}{l}\text { A hard fatty substance which is usu. obtained by rendering } \\
\text { the suet of sheep or cattle, contains stearin, palmitin, and olein, } \\
\text { and is used for making candles and soap, dressing leather, etc. }\end{array}$ \\
\hline Encarta & $\begin{array}{l}\text { Fatty substance: a hard fatty substance extracted from the } \\
\text { fat of sheep and cattle. Use: candles, soap. }\end{array}$ \\
\hline Webster & $\begin{array}{l}\text { the white nearly tasteless solid rendered fat of cattle and } \\
\text { sheep used chiefly in soap, candles, and lubricant }\end{array}$ \\
\hline Cambridge & $\begin{array}{l}\text { fat from animals which is used for making soap and, } \\
\text { especially in the past, candles }\end{array}$ \\
\hline Longman & hard animal fat used to make candles \\
\hline
\end{tabular}

'burner'

\begin{tabular}{|c|c|}
\hline Oxford & $\begin{array}{r}\text { An appliance which provides a flame for heating, lighting, etc., } \\
\text { usu. using gas or liquid fuel; the part of a lamp, cooker, etc., } \\
\text { which is the site of and shapes the flame- }\end{array}$ \\
\hline Encarta & $\begin{array}{r}\text { Part of stove or lamp: the part of a fuel-burning stove, lamp, } \\
\text { or heater that produces a flame when lit. }\end{array}$ \\
\hline Webster & $\begin{array}{r}\text { the part of a fuel-burning or heat-producing device (as a furnace } \\
\text { or stove) where the flame or heat is produced }\end{array}$ \\
\hline Cambridge & $\begin{array}{r}\text { the white nearly tasteless solid rendered fat of cattle and sheep } \\
\text { used chiefly in soap, candles, and lubricant }\end{array}$ \\
\hline Longman & the part of an oven or heater that produces heat or a flame \\
\hline
\end{tabular}

\section{'lantern'}

\begin{tabular}{|c|l|}
\hline Oxford & $\begin{array}{l}\text { A lamp consisting of) a transparent case, usu. of glass, horn, } \\
\text { paper, etc., containing and protecting a light. }\end{array}$ \\
\hline Encarta & $\begin{array}{l}\text { Portable lamp: a portable case with transparent or } \\
\text { translucent sides that protects and holds a lamp. }\end{array}$ \\
\hline Webster & $\begin{array}{l}\text { a usually portable protective case for a light with transparent } \\
\text { openings }\end{array}$ \\
\hline Cambridge & $\begin{array}{l}\text { a light inside a container which has a handle for holding it or } \\
\text { hanging it up, or the container itself }\end{array}$ \\
\hline Longman & $\begin{array}{l}\text { a lamp that you can carry, consisting of a metal container } \\
\text { with glass sides that surrounds a flame or light }\end{array}$ \\
\hline
\end{tabular}

